\title{
Понятие и характерные черты производства по делам об административных правонарушениях, осуществляемого пограничными органами в отношении юридических лиц
}

\author{
(C) Редкоус Владимир Михайлович, \\ доктор юридических наук, профессор, ведущий \\ научный сотрудник сектора административного \\ права и административного процесса Института \\ государства и права РАН \\ (C) Дуванов Николай Юрьевич, \\ кандидат юридических наук, старший препода- \\ ватель кафедры гражданско-правовых дисциплин \\ РЭУ им. Г. В. Плеханова
}

\begin{abstract}
Аннотация. В статье с позиции системного и деятельностного подходов рассмотрено понятие производства по делам об административных правонарушениях, осуществляемого пограничными органами в отношении юридических лиц. Производство по делам об административных правонарушениях, подведомственным пограничным органам, рассмотрено в качестве важнейшего вида административно-процессуальной деятельности юрисдикционного характера, осуществляемого пограничными органами в пределах своей подведомственности в контексте правового обеспечения национальной безопасности. Выделены особенности рассматриваемого производства, к которым отнесены: характер материально-правового спора, который связан с разрешением вопросов, возникающих в связи с необходимостью обеспечения государственной безопасности и национальной безопасности в целом; субъектный состав; особый характер вины юридического лица, трудности ее установления и доказывания.

Ключевые слова: административный процесс; административно-юрисдикционная деятельность; производство по делам об административных правонарушениях; пограничные органы; юридические лица; подведомственность; национальная безопасность; государственная безопасность; пограничная деятельность.
\end{abstract}

\section{The concept and characteristics of proceedings on cases of adminis- trative offenses carried out by border authorities in relation to legal entities}

\section{(C) Redkous V. M.,}

D.Sc. in law, Professor, Leading researcher of the Sector of Administrative Law and Administrative Process of the Institute of the State and Law, Russian Academy of Science

(C) Duvanov N. Ju.,

Candidate of Legal Sciences Senior Lecturer at the Department of Civil Law disciplines of the PRUE Plekhanov

Resume. The article examines the concept of proceedings in cases of administrative offenses carried out by border authorities in relation to legal entities from the standpoint of a systemic and activity-based approach. Proceedings in cases of administrative offenses subordinated to border authorities are considered as the most important type of administrative procedural activity of a jurisdictional nature, carried out by border authorities within their jurisdiction in the context of legal support of national security. The features of the proceedings under consideration are highlighted, which include: the nature of the substantive dispute, which 
is associated with the resolution of issues arising in connection with the need to ensure state security and national security in general; subject composition; the special nature of the guilt of a legal entity, the difficulty of establishing and proving it.

Key words: administrative process; administrative and jurisdictional activities; proceedings on cases of administrative offenses; border authorities; legal entities; jurisdiction; National security; state security; border activities.

Правовое обеспечение национальной безопасности является достаточно новой и недостаточно изученной категорией в юридической науке. Это касается и понятия «правовое обеспечение», и понятия «национальная безопасность». Для раскрытия темы нашего исследования необходимо учитывать следующие моменты: правовое обеспечение является более широкой категорией, чем правовое регулирование; и правовое регулирование, и правовое обеспечение могут носить так называемый отраслевой характер, становясь, например, административно-правовым обеспечением, уголовно-правовым обеспечением; национальная безопасность является более общей категорией, чем государственная и общественная безопасность, которые выступают в качестве самостоятельных видов национальной безопасности, а также стратегических национальных приоритетов, посредством реализации которых осуществляется обеспечение национальных интересов; национальная безопасность аккумулирует в себе все наиболее значимые угрозы иных видов национальной безопасности (экономической, экологической, продовольственной, информационной и иных), в том числе возникающие и в связи с деятельностью юридических лиц; пограничные органы в системе органов федеральной службы безопасности обладают многоаспектной компетенцией, и реализация ими административных полномочий исполнительнораспорядительного характера имеет как самостоятельное процессуальное значение, так и большое значение для обеспечения национальной безопасности в целом.

Поэтому правомерно производство по делам об административных правонарушениях, подведомственным пограничным органам, рассматривать в качестве важнейшего вида административно- процессуальной деятельности, осуществляемого пограничными органами в пределах своей компетенции в контексте правового обеспечения национальной безопасности. К пониманию сущности этого вида деятельности можно подойти, уяснив роль и место производства по делам об административных правонарушениях, осуществляемого пограничными органами, в административно-юрисдикционной деятельности органов федеральной службы безопасности, органов исполнительной власти Российской Федерации, а также административно-процессуальной деятельности в целом. Это важно в контексте необходимости возрождения и налаживания надлежащего систематического обучения методологии научных исследований и прикладной аналитической работы, что важно для проведения предметнопрактических исследований в области административноюрисдикционной деятельности пограничных органов, о чем справедливо говорят А. И. Землин, В. М. Корякин, А. И. Лаптева, И. В. Понкин, В. Н. Решетников, Ю. Н. Туганов и иные исследователи ${ }^{1}$.

Авторами ранее опубликован ряд работ, посвященных исследуемой теме ${ }^{2}$. Еще советскому административному праву бы-

\footnotetext{
1 Землин А. И., Корякин В. М. Методология военно-правового исследования : учебник и практикум. М.: Кнорус, 2021; Понкин И. В., Лаптева А. И. Методология научных исследований и прикладной аналитики : учебник / изд. 2-е, дополн. и перераб. М.: Буки Веди, 2021; Туганов Ю. Н. Пограничная деятельность: юридический инструментарий Кодекса Российской Федерации об административных правонарушениях нуждается в совершенствовании // Военно-юридический журнал. 2019. № 8. С. $21-$ 24, и др.

2 См., например: Редкоус В. М., Дуванов Н. Ю. Правовое регулирование применения пограничными органами мер обеспечения производства по делам об административных правонарушениях, осуществляемого в отношении юридических лиц // Военное право. 2021. № 3 (67). С. 90-106, и др.
} 
ла известна административная ответственность социалистических организаций. В настоящее время развитие рыночных отношений, усложнение экономических связей, развитие представлений о юридических лицах как субъектах административного права привело к закреплению возможности привлечения юридических лиц к административной ответственности в соответствии с действующим КоАП РФ, что, в свою очередь, привело к включенности юридических лиц в производство по делам об административных правонарушениях в качестве самостоятельного субъекта.

Современное развитие административного законодательства Российской Федерации также связано с бурным развитием его административно-процессуальных основ, механизмов привлечения к административной ответственности, усилением четкости в реализации правового положения субъектов административнопроцессуальных отношений. А. Б. Зеленцов, П. И. Кононов и А. И. Стахов связывают развитие представлений об административном процессе с «одной из насущных задач развития российского государства» ${ }^{1}$. Это является отражением общей тенденции совершенствования процессуальной регламентации всех видов государственной деятельности, так как многие материальные нормы права в сфере государственного управления не могут реализовываться без соответствующего процессуального механизма. Уже практически не возникают споры между российскими учеными о признании административнопроцессуального права в качестве самостоятельной отрасли российского права ${ }^{2}$, издается не только монографическая ${ }^{3}$, но и

\footnotetext{
1 Зеленцов А. Б., Кононов П. И., Стахов А. И. Административный процесс и административнопроцессуальное право в России: концептуальные проблемы современного развития // Административное право и процесс. 2013. № 12. С. 3.

${ }^{2}$ См., например: Попова Н. Ф. К вопросу о выделении административно-процессуального права в отдельную отрасль права // Современный юрист. 2015. № 1 (10). С. 8-17, и др.

${ }^{3}$ См., например: Сорокин В. Д. Административнопроцессуальное право : учебник. СПб: «Юридический центр Пресс, 2004 и др.
}

учебная литература ${ }^{4}$ по административнопроцессуальному праву.

Исследование понятия и правовых основ производства по делам об административных правонарушениях, осуществляемого пограничными органами, следует начинать с общих вопросов теории административного процесса и административноюрисдикционной деятельности, составной частью которой является производство по делам об административных правонарушениях ${ }^{5}$. Исследованию подлежит следующая логическая цепочка понятий: «юридический процесс» - «административный процесс (административно-процессуальная деятельность)» - «административноюрисдикционная деятельность» - «производство по делам об административных правонарушениях» — «производство по делам об административных правонарушениях, осуществляемое органами федеральной службы безопасности» - «производство по делам об административных правонарушениях, осуществляемое пограничными органами в отношении юридических лиц».

Наиболее полное представление об административном процессе можно получить, учитывая выдвинутую и обоснованную В. М. Горшеневым и его последователями теорию юридического процесса ${ }^{6}$. Их исследования значительно обогатили представление об этом сложном правовом явлении, позволили рассматривать его не только как чисто юрисдикционное явление. Преломляя выделяемые в теории юридического процесса его признаки к рассматриваемой теме исследования, можно сделать вывод, что производство по делам об административных правонаруше-

\footnotetext{
${ }^{4}$ См., например: Административно-процессуальное право : учебник / под ред. А. И. Каплунова. СПб.: Санкт-Петербургский университет МВД России, 2015 и др.

${ }^{5}$ Несмотря на существующие в науке административного права разногласия по поводу видов административно-процессуальной деятельности, а также содержательного объема административноюрисдикционной деятельности, включенность в последнюю производства по делам об административных правонарушениях является бесспорной.

6 Теория юридического процесса / под ред. В. М. Горшенева. Харьков, 1985.
} 
ниях, осуществляемое пограничными органами в рамках своей подведомственности в отношении юридических лиц, представляет собой: организационную форму деятельности, всегда связанную с разбирательством таких обстоятельств и фактов, которые основываются на праве (законе) и влекут определенные юридические последствия; совокупность правовых форм деятельности исключительно уполномоченных на то субъектов - пограничных органов и должностных лиц, специализирующихся в данной области юридической практики; органически взаимосвязанную систему действий по совершению операций с нормами права; деятельность, результат которой закрепляется принятием соответствующих правовых, имеющих официальный характер и установленную законом форму актов; деятельность, которая объективно нуждается в процессуальной регламентации; деятельность, требующую использования различных методов и средств юридической техники, достижений научно-технического прогресса; объектом правоприменения являются достаточно специфические образования - юридические лица, статус которых в административном праве является не до конца исследованным и определенным.

Развитие научных представлений о содержании административного процесса привело к формированию так называемых «управленческой» и «юрисдикционной» концепций административного процесса ${ }^{1}$, которые в настоящее время являются доминирующими. При этом продолжает активно развиваться концепция административно-судебного процесса ${ }^{2}$. Ряд ученых разрабатывают концепцию интегративного административного процесса.

${ }^{1}$ См., например: Севрюгин В. Е. О современной доктрине административного процесса России // Вестник Тюменского института повышения квалификации сотрудников МВД России. 2014. № 1 (2). С. 119-123, и др.

${ }^{2}$ См., например: Стахов А. И. Административнопроцессуальное право как регулятор административного судопроизводства в России // Административное право и процесс. 2015. № 11. С. 43-49, и др.
Управленческую концепцию административного процесса сформировали С. С. Студеникин, А. Е. Лунев и иные ученые. Так, в свое время С. С. Студеникин отмечал, что административный процесс составляет совокупность определенных правил, на основе которых осуществляется исполнительно-распорядительная деятельность. С осуществлением деятельности исполнительных органов связывал административный процесс и А. Е. Лунев. Ее последователями являются Д. Н. Бахрах, А. П. Коренев, В. М. Манохин, В. И. Новоселов, Р. С. Павловский, Г. К. Петров, Б. Д. Сорокин, О. М. Якуба и ряд других ученых, понимающих административный процесс в широком смысле.

Другие ученые - А. П. Клюшниченко, М. И. Пискотин, Н. Г. Салищева, А. В. Самойленко, В. С. Тадевосян трактуют административный процесс в боле узком смысле, связывая его только с рассмотрением административных дел. Наиболее последовательно отстаивала позицию о необходимости сужения границ административного процесса Н. Г. Салищева. По ее мнению, административный процесс представляет собой регламентированную законом деятельность по разрешению споров, возникающих между сторонами административного правоотношения, не находящимися между собой в отношениях служебного подчинения, а также по применению мер административного принуждения ${ }^{3}$. Таким образом, исходной позицией для определения понятия административного процесса в узком смысле являлся его юрисдикционный характер.

Подход В. Я. Насонова к определению административного процесса отличается большей интегративностью. В. Я. Насонов определяет административный процесс как урегулированную административнопроцессуальными нормами деятельность исполнительных органов (должностных лиц) по рассмотрению и разрешению различного рода индивидуальных административных дел, возникающих в сфере государственного управления в ходе реа-

3 Салищева Н. Г. Административный процесс в CCCP. М., 1964. C. 13, 16. 
лизации задач и функций исполнительной власти ${ }^{1}$. Этими соображениями руководствуется и Ю. М. Козлов, отмечая двоякий подход к пониманию сущности и назначения административно-процессуальной деятельности: правоприменительный (в широком смысле) и правоохранительный (в узком смысле). Ю. М. Козлов пишет, что административный процесс может быть представлен в качестве урегулированной административно-процессуальными нормами деятельностью исполнительных органов (должностных лиц) по рассмотрению и разрешению различного рода индивидуальных административных дел, возникающих в сфере государственного управления, в порядке реализации задач и функций исполнительной власти ${ }^{2}$.

Следует поддержать позицию ученых, считающих, что административнопроцессуальную деятельность нельзя ограничивать только сферой административной юрисдикции, что обусловлено следующими соображениями: юрисдикционная деятельность представляет собой лишь часть исполнительно-распорядительной деятельности, осуществляемой органами исполнительной власти; сведение административного процесса к рассмотрению только некоторых категорий дел, носящих юрисдикционный характер, означает, по существу, отрицание административнопроцессуального, управленческого характера многогранной организационной деятельности органов государственного управления; ограничение функций административного процесса выполнением юрисдикционных задач фактически выводит за его рамки рассмотрение и разрешение многообразных индивидуальных дел положительного характера, которые, в общем, и составляют большую его часть; сужение рамок административного процесса только юрисдикционной деятельностью, по сути, отождествляет его с уголовным и гражданским процессами, что нель-

\footnotetext{
${ }^{1}$ Административное право Российской Федерации : учебник / В. Я. Насонов, В. А. Коньшин, К. С. Петров, В. М. Редкоус. М.: Издательский центр «Академия», 2003. С. 65.

2 Административное право : учебник / под ред. Л. Л. Попова. М.: Юристь, 2002. С. 390.
}

зя признать правильным; расчленение административного процесса на сам процесс и административное производство как равные составляющие приводит к неправильному определению сути этих правовых явлений, поскольку производство по конкретной категории административных дел является составной частью процесса и соотносится как особенное и общее; административный процесс является формой применения системы административноправовых норм, и, более того, данный процесс обслуживает не только отрасль материального административного права, но и материальные нормы иных отраслей права, например земельного. Таким образом, понимание административного процесса в широком смысле позволяет полнее оценить его регулятивные возможности, уяснить его место и роль в системе иных процессуальных отраслей права.

Вопрос о том, что входит в структуру административного процесса, также остается дискуссионным. Так, Ю. М. Козлов считает, что важнейшими элементами, составляющими структуру административного процесса, являются административнопроцессуальные производства. Административное производство, пишет Ю. М. Козлов, это нормативно урегулированный порядок совершения процессуальных действий, обеспечивающий законное и объективное рассмотрение и разрешение индивидуальных административных дел, объединенных общностью предмета ${ }^{3}$. Видовое разнообразие административных производств может быть сведено в соответствии с классификацией административно-процессуальной деятельности к двум обобщенным группам: юрисдикционное производство и процедурное производство. Оба эти производства имеют некоторые общие черты: преимущественно внесудебный порядок разрешения индивидуальных дел; юридически-властное начало; урегулированность (однако в разной степени) административнопроцессуальными нормами; административно-процессуальные отношения и принцип и так далее.

\footnotetext{
${ }^{3}$ Там же. С. 392.
} 
В этой связи более приемлемой является позиция А. П. Алехина, в соответствии с которой административный процесс включает в себя административнопроцедурную и административноюрисдикционную процессуальную деятельность ${ }^{1}$, которые состоят из отдельных административных производств. Этот подход позволяет лучше систематизировать всю многочисленную совокупность административных производств в две вышеназванные разновидности административнопроцессуальной деятельности.

Разделение административного процесса на соответствующие виды процессуальной деятельности и процессуальные производства отражает объективную потребность общественного разделения труда и специализации деятельности различного рода субъектов, уполномоченных осуществлять такого рода деятельность. При этом выделение конкретных административных производств связано с необходимостью регулирования определенных качественно однородных общественных отношений, складывающихся в административно-процессуальной сфере и приобретающих, таким образом, характер процессуальных правоотношений.

Рассмотрим административноюрисдикционную деятельность в системе административно-процессуальной деятельности. Этимологическое понимание термина «юрисдикция» происходит от латинских слов «gus» - право и «dico» говорю. В современном русском языке слово «юрисдикция» понимается как правомочие производить суд, решать правовые вопросы. Основоположником изучения данного понятия стал А. П. Шергин, который определяет административную юрисдикцию как деятельность уполномоченных органов по рассмотрению дел об административных правонарушениях и принятию по ним соответствующего решения $^{2}$ Ю. М. Козлов определяет административную юрисдикцию как администра-

\footnotetext{
1 Алехин А. П., Кармолицкий А. А. Административное право России. Основные понятия и институты : учебник. М.: Зерцало-М, 2004. С. 297.

${ }^{2}$ Шергин А. П. Административная юрисдикция. М., 1979. C. 91.
}

тивно-процессуальную деятельность, осуществляемую во внесудебном либо судебном порядке с целью рассмотрения и разрешения административно-правовых споров и применения административнопринудительных мер ${ }^{3}$.

Есть и другие подходы к определению данного понятия. Например, Н. Г. Салищева трактует понятие административной юрисдикции как деятельности по разрешению индивидуальных дел, представляющих собой споры в сфере государственного управления ${ }^{4}$, расширяя границы этого правового явления по сравнению с А. П. Шергиным. В. Г. Розенфельд и В. В. Серегина в рассмотрении вопроса административной юрисдикции на первое место выносят административнопроцессуальную деятельность юрисдикционного характера, которая направлена на разрешение административных споров и применение мер административного принуждения, осуществляемых в России значительным числом специально уполномоченных органов исполнительной власти, отчасти органов местного самоуправления и общественных организаций, их должностных лиц во внесудебном порядке 5 .

И. П. Панова делает вывод, что административная юрисдикция есть подзаконная, правоохранительная и правоприменительная деятельность, в основном, исполнительных органов власти, осуществляемая в рамках таких законодательно закрепленных административно-юрисдикционных производств, как: а) разбирательство споров; б) применение мер административного принуждения; в) деятельность по исполнению государственного принуждения, выполняющая функции: охранительную, воспитательную, регулятивную ${ }^{6}$.

\footnotetext{
3 Административное право : учебник / под ред. Л. Л. Попова. М., 2002. С. 415.

4 Салищева Н. Г. Административный процесс в СССР. М., 1964. С. 19.

${ }^{5}$ Розенфельд В. Т., Серегина В. В. Административное принуждение (понятие, виды административного принуждения, процессуальное регулирование их применения) : учеб. пособие. Воронеж, 1996. C. 115 .

6 Панова И. В. Административно-процессуальная деятельность в Российской Федерации. Саратов, 2001. C. 47.
} 
В. В. Головко считает, что под административной юрисдикционной деятельностью следует подразумевать осуществление исполнительно-распорядительной, правоприменительной, правоохранительной, квазисудебной деятельности уполномоченными на то органами (должностными лицами) в определенной правовой сфеpe в соответствии с установленной действующим законодательством и иными нормативными правовыми актами компетенцией ${ }^{1}$.

А. И. Каплунов, А. О. Дрозд отмечают, что для понимания содержания рассматриваемого вопроса необходимо выделить две составные части: а) юрисдикцию; б) юрисдикционную деятельность. С учетом изменившегося за последние годы законодательства и появившихся в праве новых определений доктринальное толкование термина «юрисдикция» как деятельности по разрешению споров и конфликтов и принятию решения по существу дела требует своего совершенствования. Представляется верным мнение авторов о том, что административная юрисдикция - это подведомственность, полномочия или компетенция по осуществлению правоприменительной деятельности. Что же касается реализации этих полномочий, то ученые понимают ее как юрисдикционную деятельность ${ }^{2}$.

Вышеназванные подходы к определению административной юрисдикции являются по-своему верными, однако исчерпывающе не раскрывают сущность данного правового явления. Проанализировав и объединив различные точки зрения ученых, можно сделать вывод, что в науке административная юрисдикция может рассматриваться как: установленная законом совокупность правомочий соответствующих государственных органов разрешать правовые споры и дела о правонарушениях, оценивать действия лица или иного

\footnotetext{
${ }^{1}$ Головко В. В. Понятие и признаки административной юрисдикции // Научный вестник Омской академии МВД России. 2014. № 4 (55). С. 61.

${ }^{2}$ Каплунов А. И., Дрозд А. О. О предмете административной юрисдикции и понятии административно-юрисдикционной деятельности // Ленинградский юридический журнал. 2012. № 2. С. 30.
}

субъекта права с точки зрения их правомерности, применять юридические санкции к правонарушителям; территория в подведомственности определенного органа власти; отправление правосудия, а также иная деятельность государственных органов по рассмотрению споров, дел о правонарушениях и применению санкций; деятельность соответствующих органов и должностных лиц, основанная на применении норм права в сфере исполнительной власти, осуществляемая с помощью административно-юрисдикционных производств (производства по делам об административных правонарушениях, согласительного производства, производства по жалобам, дисциплинарного производства); понятие, тождественное понятию правоохранительной деятельности, так как центральное место в правоохранительной деятельности, по мнению, например С. С. Алексеева, занимает рассмотрение правового спора (юридического дела) и вынесение по нему решения ${ }^{3}$. Данная деятельность является тождественной деятельности юрисдикционной, в процессе которой находят свое применение правовые санкции и закрепляется юридическая ответственность.

До настоящего времени считается спорным вопрос о видах административноюрисдикционных производств. Так, например, И. В. Панова выделяет: а) исполнительное производство (деятельность по исполнению актов с применением мер принуждения); б) административнопроцессуальное производство (деятельность по применению мер административно-процессуального принуждения, не являющихся мерами ответственности); в) дисциплинарное производство; г) производство по жалобам; д) производство по делам об административных правонарушения ${ }^{4}$. В научной литературе указывается, что наиболее ярко выраженными видами административно-юрисдикционных производств являются: производство по делам об административных правонару-

\footnotetext{
3 Алексеев С. С. Государство и право. Начальный курс. М., 1994. С. 148.

${ }^{4}$ Панова И. В. Указ. соч. С. $116-118$.
} 
шениях; дисциплинарное производство, производство по жалобам ${ }^{1}$. Указанные производства соотносятся с административным процессом как категории особенного и общего и входят в качестве обособленного элемента в его структуру. Этот подход поддерживают В. Я. Насонов, В. А. Коньшин, К. С. Петров и др. ${ }^{2}$

Эти определения позволяют выделить наиболее характерные черты административно-юрисдикционной деятельности: административно-юрисдикционная деятельность - важнейшая составляющая административного процесса и юридического процесса вообще, носящая преимущественно правоохранительный характер ${ }^{3}$; административно-юрисдикционная деятельность представляет собой лишь часть исполнительно-распорядительной деятельности, осуществляемой органами исполнительной власти. Ю. М. Козлов отмечает, что административно-юрисдикционная деятельность не является главным и определяющим содержание государственно-управленческой деятельности признаком $^{4}$; являясь процессуальной деятельностью, административно-юрисдикционная деятельность имеет свои цель и задачи, функции, стадии, субъекты осуществления, формы и методы, средства (меры) обеспечения; административноюрисдикционная деятельность применяется во внесудебном порядке уполномоченными органами исполнительной власти (их должностными лицами); предметом административно-юрисдикционной деятельности являются возникшие в определенной области государственного управления конкретные административно-правовые споры; в ходе административноюрисдикционной деятельности осуществляется правовая оценка поведения сторон

1 Административное право : учебник / под ред. Л. Л. Попова. М., 2002. С. 415-419.

${ }^{2}$ Административное право Российской Федерации : учебник / В. Я. Насонов, В. А. Коньшин, К. С. Петров, В. М. Редкоус. С. 70.

${ }^{3}$ Например, можно еще выделить правообеспечительный, профилактический характер административной юрисдикции.

4 Административное право : учебник / под ред. Л. Л. Попова. М., 2002. С. 408-415. возникшего административного спора; административно-юрисдикционная деятельность связана с возможностью применения мер устанавливаемой нормами административного права юридической ответственности к виновной стороне административно-правового спора, а также иных мер принуждения.

Вышеназванное создает основу для выработки определения понятия административно-юрисдикционной деятельности, осуществляемой пограничными органами. Следует поддержать определение, выработанное М. П. Тереховой, определяющей административно-юрисдикционную деятельность пограничных органов как деятельность пограничных органов и их должностных лиц в пределах их компетенции, осуществляемую во внесудебном порядке в рамках административнопроцессуальной деятельности федеральной службы безопасности, направленную на рассмотрение и разрешение возникающих в области осуществления пограничной деятельности административно-правовых споров, правовую оценку поведения их участников и применение к виновной стороне в необходимых случаях мер юридической ответственности ${ }^{5}$.

По мнению авторов, для формулирования определения производства по делам об административных правонарушениях, осуществляемого пограничными органами, необходимо опираться на определение производства по делам об административных правонарушениях, осуществляемого органами федеральной службы безопасности, а также проанализировать предлагаемые в научной и учебной литературе определения данного вида производства. Большинством ученых производство по делам об административных правонарушениях определяется с учетом положений ст. 24.1. КоАП РФ, устанавливающей его задачи.

Так, например, А. П. Алехин определяет производство по делам об административных правонарушениях как урегу-

\footnotetext{
${ }^{5}$ Редкоус В. М., Терехова М. Понятие административно-юрисдикционной деятельности пограничных органов // Закон и право. 2011. № 4. С. 107.
} 
лированную

административнопроцессуальными нормами деятельность уполномоченных органов и должностных лиц по пресечению, объективному рассмотрению и законному назначению наказания лицу, совершившему административное правонарушение, а также его исполнению ${ }^{1}$. По мнению авторов, в данном определении не отражается предупредительно-профилактическая направленность производства, что конкретно закреплено в ст. 24.1. КоАП РФ: «Задачами производства по делам об административных правонарушениях являются ... также выявление причин и условий, способствовавших совершению административных правонарушений». В определении производства по делам об административных правонарушениях, предложенного в работе Д. Н. Бахраха и Э. Н. Ренова ${ }^{2}$, просто затушевываются основные задачи производства, закрепленные в ст. 24.1 КоАП РФ.

В. Д. Сорокин, рассматривая производство по делам об административных правонарушениях, выделяет обстоятельства, говорящие об особом месте данного производства в административном процессе в целом ${ }^{3}$. К ним он относит следующие: неразрывная связь с такой формой государственного принуждения, как административная ответственность; практическая потребность, которая выражается в необходимости четкого правового регулирования института административной ответственности; обеспечение материальноюридической природы института административной ответственности и приобретение в связи с этим стабильности, упорядоченности и стройности; большой научный интерес, так как производство по делам об административных правонарушениях признается и представителями «юрисдикционной», и «управленческой» концепций административного процесса.

В учебнике под редакцией П. И. Кононова, В. Я. Кикотя, И. Ш. Килясханова производство по делам об административ-

1 Алехин А. П., Кармолицкий А. А. Указ. соч. C. 299.

${ }^{2}$ Бахрах Д. Н., Ренов Э. Н. Указ. соч. С. 101.

${ }^{3}$ Сорокин В. Д. Административно-процессуальное право. С. $494-498$. ных правонарушениях определяется как «основанная на законе и облеченная в форму правовых отношений деятельность судей, органов и должностных лиц по возбуждению и рассмотрению дел об административных правонарушениях, а также применению к виновным мер административной ответственности, осуществляемая в особом административно-процессуальном порядке в целях всестороннего, полного, объективного и своевременного выяснения обстоятельств каждого дела, разрешения его в соответствии с законом, обеспечения исполнения вынесенного постановления, а также выявления причин и условий, способствовавших совершению административных правонарушений» ${ }^{4}$.

Д. Р. Кеворков определяет производство по делам об административных правонарушениях применительно к теме своего исследования как «часть административно-юрисдикционного процесса, то есть, урегулированную нормами административного права деятельность должностных лиц пограничных органов и пограничных войск по возбуждению, рассмотрению дела об административном правонарушении, исполнению принятых по делу постановлений, а в случае необходимости - административному расследованию, пересмотру постановлений, решений по делу об административном правонарушении, а также применению мер обеспечения производства» ${ }^{5}$. В основу своего, в принципе, верного определения Д. Р. Кеворков положил стадийность производства по делам об административных правонарушениях. Однако, по мнению авторов, это определение следовало бы уточнить. Не всегда должностные лица органов исполнительной власти, уполномоченные составлять протоколы об административных правонарушениях (ст. 28.3. КоАП РФ), уполномочены рассматривать соответствующие дела

\footnotetext{
${ }^{4}$ Административное право России : учебник / под. ред. П. И. Кононова, В. Я. Кикотя, И. Ш. Килясханова. 4-е изд. перераб. и доп. М., 2009. С. 446.

${ }^{5}$ Кеворков Д. Р. Правовые основы производства по делам об административных правонарушениях в пограничных органах и пограничных войсках Федеральной службы безопасности Российской Федерации : дис. ... канд. юрид. наук. М., 2004. С. 34.
} 
(гл. 23 КоАП РФ). Также, по мнению авторов, не совсем корректно включать меры обеспечения производства по делам об административных правонарушениях в само производство, хоть этот вопрос следует отнести к спорным. Необходимо четко выдерживать методологический подход, изложенный В. Д. Сорокиным: производство по делу, в первую очередь, направлено на четкое правовое регулирование института административной ответственности.

Также Д. В. Кеворков в своей диссертации предложил следующее определение производства по делам об административных правонарушениях в пограничных органах и пограничных войсках: это часть административно-юрисдикционного процесса, то есть урегулированная нормами административного права деятельность должностных лиц пограничных органов и пограничных войск по возбуждению, рассмотрению дела об административном правонарушении, исполнению принятых по делу постановлений, а в случае необходимости - административному расследованию, пересмотру постановлений, решений по делу об административном правонарушении, а также применению мер обеспечения производства ${ }^{1}$.

Для определения производства по делам об административных правонарушениях, осуществляемого органами федеральной службы безопасности, кроме учета положений ст. 24.1 КоАП РФ просто необходимо учитывать предназначение и специфику деятельности органов федеральной службы безопасности.

С учетом вышеизложенного производство по делам об административных правонарушениях, осуществляемое органами федеральной службы безопасности, необходимо рассматривать как важнейшую разновидностью административной деятельности органов федеральной службы безопасности, связанную с реализацией органами безопасности внешних исполнительно-распорядительных полномочий, и представляющую собой урегулированную административно-процессуальными нормами и осуществляемую во внесудебном

\footnotetext{
${ }^{1}$ Там же. С. $142-164$
}

порядке деятельность уполномоченных органов, подразделений и должностных лиц органов федеральной службы безопасности, направленную на всестороннее, полное, объективное и своевременное выяснение обстоятельств каждого дела об административном правонарушении, подведомственного органам федеральной службы безопасности, разрешение его в соответствии с законом, обеспечение исполнения вынесенного постановления, выяснение причин и условий, способствовавших совершению административных правонарушений, а также на создание условий для эффективного осуществления органами федеральной службы безопасности законодательно закрепленных направлений деятельности в целях обеспечения безопасности Российской Федерации. Полномочия органов федеральной службы безопасности по осуществлению производства по делам об административных правонарушениях — важнейшая часть их компетенции, установленной федеральным законодательством.

Определения производства по делам об административных правонарушениях КоАП РФ не дает, однако в разделах и включенных в них главах закрепляет процессуальные основы его осуществления. В административном праве данное производство рассматривается в рамках административного процесса и административноюрисдикционной деятельности. При выработке требуемого определения необходимо отразить процессуальный характер данного понятия, и его направленность на достижение задач производства по делам об административных правонарушениях, закрепленных в ст. 24.1 КоАП РФ.

Категория «подведомственность» находит свое официальное применение в юридической науке и законодательстве. Под подведомственностью понимается механизм распределения юридических дел между различными юрисдикционными органами ${ }^{2}$, в связи с чем при установлении критериев подведомственности необходимо учитывать соотношение следующих

\footnotetext{
2 Осипов Ю. Н. Подведомственность юридических дел. Свердловск, 1973. С. 83.
} 
факторов: материально-правовой характеристики подлежащего разрешению дела и сущности юрисдикционного органа. Под подведомственностью также понимают относимость нуждающихся в государственно-властном разрешении споров о праве и иных дел к ведению различных государственных, общественных, смешанных органов и третейских судов, как свойство юридических дел, в силу которых они подлежат разрешению определенными юридическими органами, отнесение спора о праве или иного юридического дела к компетенции определенного органа. Критериям разграничения подведомственности являются: субъектный состав, характер материально-правового спора, указание в самом законе об отнесении дела к подведомственности судов общей юрисдикции или арбитражных судов и другие в зависимости от правовой ситуации. Игнорирование указанных факторов отражается на эффективности осуществления органом своей деятельности и действенности защиты прав и интересов участников отношений, из которых возникло подлежащее разрешению дело. Подведомственность является одной из обязательных предпосылок, дающих возможность юридически заинтересованному лицу реализовать свое право на судебную защиту.

В административном праве с подведомственностью связывается, прежде всего, подчиненность одной организации другой, и, во-вторых, отнесенность определенных юридических дел к компетенции (ведению) определенного органа (должностного лица). Под подведомственностью дел об административных правонарушениях пограничным органам следует понимать отнесение законом определенных юридических дел к компетенции (ведению) пограничных органов. Критериями разграничения подведомственности выступают: характер материально-правового спора; субъектный состав; указание в КоАП РФ об отнесении дел об административных правонарушениях к подведомственности федеральной службы безопасности в зависимости от правовой ситуации.

Подведомственность дел об административных правонарушениях погранич- ным органам базируется на соответствующих положениях КоАП РФ (ч. 1 ст. 23.10; ч. 1 ст. 23.52 ; п. 14 ч. 2 ст. 28.3 ; п. 66 ч. 2 ст. 28.3; абзацах втором и третьем ч. 3 ст. 28.3 КоАП РФ), которые устанавливают полномочия пограничных органов по возбуждению и рассмотрению дел об административных правонарушениях, а также очерчивают пределы реализации пограничными органами административноюрисдикционной компетенции в отношений ряда правонарушений, составы которых закреплены в главах 7, 8, 17, 18, 19 КоАП РФ.

В данных правовых отношениях пограничные органы выступают как: собственно пограничные органы (ст. 23.10, п. 14 ч. 2 ст. 28.3 КоАП РФ); органы, осуществляющие государственный контроль и надзор за соблюдением обязательных требований к продукции и государственный метрологический надзор (ст. 23.52 КоАП РФ); как структурное подразделение федерального органа исполнительной власти, территориальные органы, уполномоченные осуществлять производство по делам об административных правонарушениях в соответствии с КоАП РФ (абзац второй ч. 3 ст. 28.3 КоАП РФ); как структурное подразделение федерального органа исполнительной власти, территориальные органы, уполномоченные осуществлять государственный контроль (надзор) (абзац третий ч. 3 ст. 28.3 КоАП РФ).

Таким образом, производство по делам об административных правонарушениях, осуществляемое пограничными органами, направлено на решение стоящих перед органами федеральной службы безопасности, пограничными органами задач по обеспечению безопасности Российской Федерации посредством реализации института административной ответственности.

Производство по делам об административных правонарушениях, подведомственных пограничным органам ФСБ России, осуществляемое в отношении юридических лиц, представляет собой разновидность административно-юрисдикционной деятельности, осуществляемой пограничными органами и их должностными лицами в целях всестороннего, полного, объек- 
тивного и своевременного выяснения обстоятельств каждого дела, разрешения его в соответствии с законом, обеспечения исполнения вынесенного постановления, выявления причин и условий, способствовавших совершению административных правонарушений юридическими лицами в области защиты государственной границы Российской Федерации и обеспечения режима пребывания иностранных граждан или лиц без гражданства на территории Российской Федерации; охраны собственности; охраны окружающей среды и природопользования, а также административных правонарушений, посягающих на институты государственной власти и административных правонарушений против порядка управления.

Для определения характерных черт производства по делам об административных правонарушениях, осуществляемых пограничными органами в отношении юридических лиц, определяющим будут следующие положения законодательных актов Российской Федерации:

a) положения Федерального закона от 3 апреля 1995 г. № 40-Ф3 «О федеральной службе безопасности»:

- ч. 1 ст. 1 - «Федеральная служба безопасности - единая централизованная система органов федеральной службы безопасности, осуществляющая решение в пределах своих полномочий задач по обеспечению безопасности Российской Федерации»;

- ст. 8, устанавливающая, что пограничная деятельность является наравне с контрразведывательной деятельностью, борьбой с терроризмом, борьбой с преступностью, разведывательной деятельностью, обеспечением информационной безопасности одним из основных направлений деятельности органов федеральной службы безопасности;

- ст. 11.1, закрепляющая, что «направлениями пограничной деятельности являются:

защита и охрана Государственной границы Российской Федерации в целях недопущения противоправного изменения прохождения Государственной границы Российской Федерации, обеспечения со- блюдения физическими и юридическими лицами режима Государственной границы Российской Федерации, пограничного режима и режима в пунктах пропуска через Государственную границу Российской Федерации;

защита и охрана экономических и иных законных интересов Российской Федерации в пределах приграничной территории, исключительной экономической зоны и континентального шельфа Российской Федерации, а также охрана за пределами исключительной экономической 3оны Российской Федерации запасов анадромных видов рыб, образующихся в реках Российской Федерации, трансграничных видов рыб и далеко мигрирующих видов рыб в соответствии с международными договорами Российской Федерации и (или) законодательством Российской Федерации»;

пункт «г.1» ст. 12, устанавливающий обязанность органов федеральной службы безопасности «выявлять, предупреждать и пресекать административные правонарушения, возбуждение и (или) рассмотрение дел о которых отнесены Кодексом Российской Федерации об административных правонарушениях к ведению органов федеральной службы безопасности»;

пункт «г.1» ст. 13, устанавливающий право органов федеральной службы безопасности «составлять протоколы об административных правонарушениях, выносить определения и постановления по делам об административных правонарушениях, назначать административные наказания по делам об административных правонарушениях, вносить представления об устранении причин и условий, способствовавших совершению административных правонарушений, и осуществлять иные полномочия по делам об административных правонарушениях, отнесенным Кодексом Российской Федерации об административных правонарушениях к ведению органов федеральной службы безопасности»;

б) положения Закона Российской Федерации от 1 апреля 1993 г. № 4730-I «O Государственной границе Российской Федерации»: 
- абз. 4 ч. 1 ст. 30, устанавливающий, что пограничные органы «осуществляют производство по делам об административных правонарушениях, отнесенным к их ведению законодательством Российской Федерации, в пределах своей компетенции рассматривают эти дела и исполняют постановления по ним» в целях охраны Государственной границы на суше, море, реках, озерах и иных водных объектах, в пунктах пропуска через Государственную границу, а также осуществления пропуска через Государственную границу.

Особенностями рассматриваемого производства являются:

- во-первых, характер материальноправового спора, который связан с разрешением вопросов, возникающих в связи с необходимостью обеспечения государственной безопасности и национальной безопасности в целом;

- во-вторых, субъектный состав. С одной стороны, это пограничные органы, а с другой - юридические лица, правовое положение которых во многом определяется нормами гражданского законодательства. Если организация не будет отвечать критериям юридического лица, она не может быть привлечена к административной ответственности как юридическое лицо;

— в-третьих, особый характер вины юридического лица, трудности ее установления и доказывания.

\section{Библиография}

1. Административное право : учебник / под ред. Л. Л. Попова. - М.: Юристъ, 2002.

2. Административное право Российской Федерации : учебник / В. Я. Насонов, В. А. Коньшин, К. С. Петров, В. М. Редкоус. - М.: Издательский центр «Академия», 2003.

3. Административно-процессуальное право : курс лекций / под ред. проф. И. Ш. Килясханова. М.: ЮНИТИ-ДАНА, 2004. - 399 с.

4. Административно-процессуальное право : учебник / под ред. А. И. Каплунова. - СПб.: Санкт-Петербургский университет МВД России, 2015. - $376 \mathrm{c}$.

5. Административное право России : учебник / под ред. П. И. Кононова, В. Я. Кикотя, И. Ш. Килясханова. 4-е изд. перераб. и доп. - М.: ЮНИТИДАНА: Закон и право, 2009.

6. Алексеев, С. С. Государство и право. Начальный курс / С. С. Алексеев. - М.: Юрид. лит., 1994. - $192 \mathrm{c}$.
7. Алехин, А. П. Административное право России. Основные понятия и институты : учебник / А. П. Алехин, А. А. Кармолицкий. - М.: ЗерцалоM, 2004.

8. Бахрах, Д. Н. Административная ответственность по российскому законодательству / Д. Н. Бахрах, Э. Н. Ренов. - М.: Норма, 2004. $304 \mathrm{c}$.

9. Головко, В. В. Понятие и признаки административной юрисдикции / В. В. Головко // Научный вестник Омской академии МВД России. 2014. — № 4 (55). — С. 60-63.

10. Зеленцов, А. Б. Административный процесс и административно-процессуальное право в России: концептуальные проблемы современного развития / А. Б. Зеленцов, П. И. Кононов, А. И. Стахов // Административное право и процесс. - 2013. - № 12. - С. 3-15.

11.Землин, А. И. М. Методология военноправового исследования : учебник и практикум / А. И. Землин, В. М. Корякин. - М.: Кнорус, 2021. $-228 \mathrm{c}$.

12. Каплунов, А. И. О предмете административной юрисдикции и понятии административноюрисдикционной деятельности / А. И. Каплунов, А. О. Дрозд // Ленинградский юридический журнал. - 2012. - № 2 .

13. Кеворков, Д. Р. Правовые основы производства по делам об административных правонарушениях в пограничных органах и пограничных войсках Федеральной службы безопасности Российской Федерации : дис. ...канд. юрид. наук / Д. Р. Кеворков. - М., 2004. - 205 с.

14. Осипов, Ю. Н. Подведомственность юридических дел / Ю. Н. Осипов. - Свердловск, 1973. $-121 \mathrm{c}$.

15. Панова, И. В. Административнопроцессуальная деятельность в Российской Федерации / И. В. Панова. - Саратов, 2001.

16. Понкин, И. В. Методология научных исследований и прикладной аналитики : учебник. Изд. 2-е, дополн. и перераб. / И. В. Понкин, А. И. Лаптева. - М.: Буки Веди, 2021.

17. Попова, Н. Ф. К вопросу о выделении административно-процессуального права в отдельную отрасль права / Н. Ф. Попова // Современный юрист. - 2015. - № 1 (10). - С. 8-17.

18. Редкоус, В. М. Понятие административноюрисдикционной деятельности пограничных органов / В. М. Редкоус, М. Терехова // Закон и право. - 2011. — № 4.

19. Редкоус, В. М. Правовое регулирование применения пограничными органами мер обеспечения производства по делам об административных правонарушениях, осуществляемого в отношении юридических лиц / В. М. Редкоус, Н. Ю. Дуванов // Военное право. — 2021. — № 3 (67). — С. 90-106.

20. Разоренов, К. И. Об управленческой и юрисдикционной концепциях административного процесса / К. И. Разоренов // Проблемы укрепления законности и правопорядка: наука, практика, тенденции. - 2009. — № 2. - С. 49-57. 
21. Розенфельд, В. Т. Административное принуждение (понятие, виды административного принуждения, процессуальное регулирование их применения) : учеб. пособие / В. Т. Розенфельд, В. В. Серегина. - Воронеж, 1996.

22. Салищева, Н. Г. Административный процесс в СССР / Н. Г. Салищева. - М.: Юрид. лит., 1964. $-158 \mathrm{c}$.

23. Севрюгин, В. Е. О современной доктрине административного процесса России / В. Е. Севрюгин // Вестник Тюменского института повышения квалификации сотрудников МВД России. - 2014. — № 1 (2). — С. 119-123.

24. Стахов, А. И. Административнопроцессуальное право как регулятор административного судопроизводства в России / А. И. Стахов // Административное право и процесс. - 2015. № 11. - С. 43-49.

25. Сорокин, В. Д. Административно-процессуальное право : учебник / В. Д. Сорокин. - СПб.: «Юридический центр Пресс», 2004. — 540 с.

26. Студеникин, С. С. Социалистическая система государственного управления и вопрос о предмете административного права / С. С. Студеникин // Вопросы советского административного права. - М., 1949.

27. Теория юридического процесса / под ред. В. М. Горшенева. - Харьков, 1985. - 192 с.

28. Туганов, Ю. Н. Прекращение дел об административных правонарушениях, освобождение военнослужащих, совершивших правонарушения, от административной ответственности / Ю. Н. Туганов // Право в Вооруженных Силах — военноправовое обозрение. — 2014. — № 1 (199). C. $10-19$.

29. Туганов, Ю. Н. Пограничная деятельность: юридический инструментарий Кодекса Российской Федерации об административных правонарушениях нуждается в совершенствовании / Ю. Н. Туганов // Военно-юридический журнал. - 2019. — № 8. C. $21-24$.

30. Шергин, А. П. Административная юрисдикция : монография / А. П. Шергин. - М.: Научиздат, 1979. - 641 с. 